\title{
Molecular detection and quantification of nifH gene sequences in the rhizosphere of sorghum (Sorghum bicolor) sown with two levels of nitrogen fertilizer
}

\author{
Marcia R.R. Coelho a,b ${ }^{\text {, Ivanildo E. Marriel }}{ }^{\text {, }}$, Sasha N. Jenkins ${ }^{\text {b,1 }}$, Clare V. Lanyon ${ }^{\mathrm{b}}$, Lucy Seldin ${ }^{\mathrm{a}, *}$, \\ Anthony G. O’Donnell ${ }^{\mathrm{b}, 1}$ \\ ${ }^{a}$ Instituto de Microbiologia Prof. Paulo de Góes, Universidade Federal do Rio de Janeiro, Rio de Janeiro, RJ, Brazil \\ ${ }^{\mathrm{b}}$ Institute for Research in Environment and Sustainability, Newcastle University, Newcastle upon Tyne NE1 7RU, UK \\ ${ }^{\mathrm{c}}$ EMBRAPA/CNPMS - Empresa Brasileira de Pesquisa Agropecuária, Centro Nacional de Pesquisas de Milho e Sorgo, Sete Lagoas, MG, Brazil
}

\section{A R T I C L E I N F O}

\section{Article history:}

Received 21 October 2008

Received in revised form 28 January 2009

Accepted 29 January 2009

\section{Keywords:}

Real-time PCR

DGGE

nifH gene

Sorghum bicolor

Diazotrophs

\begin{abstract}
A B S T R A C T
Denaturing gradient gel electrophoresis (DGGE) and SYBR Green I quantitative real-time PCR (qPCR) approaches were used to assess respectively the molecular diversity and the quantity of the nifH gene sequences in the rhizospheres of two cultivars of sorghum sown in Cerrado soil with contrasting levels of nitrogen fertilizer. DGGE fingerprinting showed that for both cultivars the presumptive nitrogen-fixing populations in the rhizospheres were more diverse than in bulk soil. Sequencing of nifH gene fragments obtained from DGGE bands revealed that members of the order Rhizobiales were prevalent among the dominant diazotrophs. Discriminant analysis of DGGE profiles resulted into three groups formed by (i) cultivar BRS 308 sown with high level of nitrogen, (ii) cultivar BRS 308 sown with low level of nitrogen and cultivar BRS 310 sown either with low or high levels of nitrogen and (iii) bulk soil, showing that the nitrogen fertilization influenced the nifH gene sequence diversity only in the rhizosphere of cultivar BRS 308. When the quantity of the nifH gene sequences was determined by q-PCR, $2.4 \times 10^{5}$ to $1.3 \times 10^{7}$ copies/g of soil were detected. The highest number of nifH gene copies was observed in the rhizosphere of cultivar BRS 308 treated with low amount of fertilizer, and a reduction in nifH density was observed in the rhizospheres of both sorghum cultivars when high levels of nitrogen were applied. Thus, both the amount of nitrogen fertilizer and the cultivar are important factors influencing the structure and amount of diazotrophs in sorghum.
\end{abstract}

(c) 2009 Elsevier B.V. All rights reserved.

\section{Introduction}

Phylogenetically diverse groups of prokaryotic organisms, belonging to the Bacteria and Archaea domains, are capable of biological nitrogen fixation (BNF; Young, 1992; Zehr et al., 2003). In agricultural systems, BNF is particularly important as nitrogen is usually the limiting nutrient for crop growth and also makes the reduction of atmospheric nitrogen into bioavailable ammonium an important source of nitrogen input (Demba Diallo et al., 2004; Wartiainen et al., 2008). Nitrogen fixation by free-living soil microorganisms is sometimes considered a minor source of nitrogen input in soil when compared to systems such as the Rhizobium-

\footnotetext{
* Corresponding author at: Laboratório de Genética Microbiana, Instituto de Microbiologia Prof. Paulo de Góes, Universidade Federal do Rio de Janeiro, Av. Carlos Chagas Filho, 373, Centro de Ciências da Saúde, Bloco I, Ilha do Fundão, CEP 21941590 Rio de Janeiro, RJ, Brazil. Tel.: +55 212562 6741/55 219989 7222; fax: +55212560 8344 .

E-mail addresses: lseldin@micro.ufrj.br, lucy@seldin.com.br (L. Seldin).

${ }^{1}$ Current address: Faculty of Natural and Agricultural Sciences, The University of Western Australia, Crawley, WA 6009, Australia.
}

legume symbiosis (Peoples and Craswell, 1992; Kanungo et al., 1997). However, non-symbiotic nitrogen fixation occurs in most soils and has been shown to be the dominant source of fixed nitrogen in different soils (Widmer et al., 1999; Lovell et al., 2000; Poly et al., 2001a). Putative diazotrophs belonging to the alpha, beta and gammaproteobacteria, Cyanobacteria and Firmicutes have already been found in soil and rhizosphere samples (Widmer et al., 1999; Poly et al., 2001a; Coelho et al., 2008).

The nifH gene which encodes the iron protein subunit of nitrogenase is highly conserved among diazotrophs, and a good phylogenetic correlation has been found between nifH and the 16S rRNA gene (Young, 1992; Zehr et al., 2003). However, as a functional gene, nifH has the advantage that it provides evidence for potential nitrogen fixation (Young, 1992). Moreover, the nifH gene is the most thoroughly studied gene of the nif operon, with an extensive collection of sequences obtained from both cultured and uncultivated microorganisms isolated from multiple environments (Ueda et al., 1995; Tan et al., 2003; Zehr et al., 2003; Demba Diallo et al., 2004; Deslippe and Egger, 2006).

Cultivation-independent studies using clone library analyses (Zhang et al., 2006; Coelho et al., 2008), denaturing gradient gel 
electrophoresis (DGGE) (Piceno and Lovell, 2000; Wartiainen et al., 2008) and terminal or complete restriction fragment length polymorphism (RFLP) methods (Poly et al., 2001b) have already shown the great diversity of nifH genes in natural environments. Despite this extensive knowledge base, little is known about the assemblages of nitrogen-fixing bacteria and archaea in complex soil environments (Izquierdo and Nusslein, 2006). One of the current challenges faced by microbial ecologists is how best to relate information on the abundance of specific bacterial populations in the environment with their functional activity (Gray and Head, 2001). Measuring the relative abundance and dynamics of functional genes, as an indicator of potential activity, may help link data on community structure with that on function. Real-time quantitative PCR (qPCR) has been used successfully to determine the abundance of nifH sequences in marine environments and patterns in the vertical, temporal, and seasonal distributions of nifH phylotypes (Church et al., 2005a,b; Short and Zehr, 2005). Juraeva et al. (2006) described a method to quantify nifH gene copy number in plants using qPCR and SYBR Green I, and used this to evaluate the direct contribution of plant-inhabiting diazotrophs to plant nitrogen nutrition in cucumber. Wallenstein and Vilgalys (2005) developed techniques to quantify several important nitrogen functional genes, including nifH, from two forest soils using quantitative real-time PCR. Soils differed greatly in their relative abundance of nitrogen functional genes, which could reflect the different nitrogen cycling processes in these soils.

In a previous study, Coelho et al. (2008) found that the level of nitrogen used was the determinative factor influencing the structure of the diazotroph community when analyzing clone libraries of the nifH gene pool in the rhizosphere of experimental cultivars of sorghum sown with contrasting levels of nitrogen fertilizer. In the present study, we have used DGGE to investigate the influence of low and high nitrogen fertilizer inputs (12 and $120 \mathrm{~kg} /$ ha respectively) and sorghum cultivar (BRS 308 and BRS 310) on the structure of the nitrogen-fixing bacterial community. Furthermore, qPCR was used to estimate the effects of plant cultivar and the rate of nitrogen input on total nifH gene abundance.

\section{Materials and methods}

\subsection{Experimental conditions, soil and sorghum cultivars}

The field experiment was carried out at EMBRAPA Maize and Sorghum, Sete Lagoas, Minas Gerais, Brazil, located at latitude $19^{\circ} 28^{\prime} \mathrm{S}$ and longitude $44^{\circ} 15^{\prime} \mathrm{W}$, at a height of $732 \mathrm{~m}$. The local climate is of the savannah type, with a mean temperature in the coldest month above $18{ }^{\circ} \mathrm{C}$. The soil planted with two different cultivars of sorghum (Sorghum bicolor) was classified as a clayey Distrophic Red Latosol (Oxisol), Cerrado stage (coarse sand 6\%, fine sand $4 \%$, silt $12 \%$, and clay $78 \%$ ). Physical and chemical analyses of the soil showed low organic matter content $\left(3.27 \mathrm{dag} / \mathrm{dm}^{3}\right)$, a $\mathrm{pH}$ value of 6.2 , and $\mathrm{P}, \mathrm{K}, \mathrm{Ca}$, and $\mathrm{Mg}$ contents of $11,80,5.85$ and $0.87 \mathrm{cmolc} / \mathrm{dm}^{3}$, respectively. The two commercial sorghum cultivars (BRS 308 and BRS 310) were chosen based on their agricultural importance. Briefly, they can be described as follows: BRS 308, red grain, three-dwarf, 65-70 days from planting to flowering, and a grain productivity of $5490 \mathrm{~kg} / \mathrm{ha}$; BRS 310, red grain, three-dwarf, 65 days from planting to flowering, and a grain productivity of $5270 \mathrm{~kg} / \mathrm{ha}$. The experimental design consisted of two lines of $5 \mathrm{~m}$ of length with spaces of $0.8 \mathrm{~m}$ between lines and $0.2 \mathrm{~m}$ between plants. Cultivars were planted randomly in each line. One line received $12 \mathrm{~kg}$ of nitrogen/ha (low concentration of nitrogen) and the other $120 \mathrm{~kg}$ of nitrogen/ha (high concentration of nitrogen). Five plants of each sorghum cultivar were harvested 90 days after sowing and the roots shaken to remove the loosely attached soil. The adhering soil of the five plants was pooled and considered as the rhizosphere soil. Samples were kept at $-20^{\circ} \mathrm{C}$ before DNA extraction.

\subsection{DNA extraction from bulk and rhizosphere soils}

DNA was extracted from rhizospheric and non-rhizospheric (bulk) soil samples in triplicate ( $0.5 \mathrm{~g}$ of each sample) according to the method of Griffiths et al. (2000). Extracted DNAs were visualized on $0.8 \%(\mathrm{w} / \mathrm{v})$ agarose gels to assess their integrity and then stored at $4{ }^{\circ} \mathrm{C}$ prior to PCR amplification.

\subsection{PCR amplification of nifH gene for DGGE analysis}

The nifH DNA sequences in the soil samples were amplified using a nested PCR as described by Demba Diallo et al. (2004). The first PCR was carried out with the forward primer FGPH19 and the reverse primer PolR (Table 1; Simonet et al., 1991; Poly et al., 2001b) generating a product of $429 \mathrm{bp}$. The second PCR was carried out with the forward primer PolF containing a GC clamp and the reverse primer AQER (Table 1; Poly et al., 2001b), yielding a product of $320 \mathrm{bp}$ (including the GC clamp sequence). The $30 \mu$ l reaction mix contained: $1 \mu$ l of template DNA (50-100 ng), $5 \mu$ l of $10 \times$ PCR buffer (100 mM Tris- $\mathrm{HCl}, \mathrm{pH}$ 9; $500 \mathrm{mM} \mathrm{KCl}$ ), $1.5 \mathrm{mM} \mathrm{MgCl} 2,0.5 \mathrm{mM}$ of each primer, $200 \mathrm{mM}$ of each dNTPs and $2.5 \mathrm{U}$ of Taq DNA polymerase. For the second PCR, $1 \mu$ l of the first PCR product was used as a template. The amplification conditions used were: 30 cycles consisting of denaturation at $94{ }^{\circ} \mathrm{C}$ for $1 \mathrm{~min}$, annealing for 1 min at $55^{\circ} \mathrm{C}$ for the first PCR and at $48{ }^{\circ} \mathrm{C}$ for the second PCR, primer extension at $72{ }^{\circ} \mathrm{C}$ for $2 \mathrm{~min}$, with a final extension at $72{ }^{\circ} \mathrm{C}$ for $5 \mathrm{~min}$. Negative controls (without DNA) were run in all amplifications. PCR products were analyzed by $1.5 \%$ agarose gel electrophoresis followed by staining with ethidium bromide to confirm their sizes.

\subsection{DGGE}

DGGEs were carried out using the D-Code system from Bio-Rad Laboratories. PCR products $(10-15 \mu \mathrm{l})$ were loaded onto $8 \%(\mathrm{w} / \mathrm{v})$ polyacrylamide gels, $1 \mathrm{~mm}$ thick, in $1 \times$ TAE buffer $(20 \mathrm{mM}$ Trisacetate, $\mathrm{pH} 7.4,10 \mathrm{mM}$ acetate, $0.5 \mathrm{mM}$ disodium EDTA). The denaturing gradient contained a linear denaturing gradient from 20 to $70 \%$ [ $100 \%$ denaturant corresponded to $7 \mathrm{M}$ urea and $40 \%(\mathrm{v} / \mathrm{v}$ ) deionized formamide]. Electrophoresis was performed at a constant voltage of $200 \mathrm{~V}$ for $4 \mathrm{~h}$. After electrophoresis, the gels were stained for 30 min with SYBR Green I nucleic acid gel stain (Molecular Probes, Oregon, USA) and digitized using a Bio-Rad Fluor MultiImager (BioRad Laboratories, Hemel Hempstead, UK). This procedure was semi-automated using the software package BIONUMERICS 2.5. (Applied Maths, Sint-Martens-Latem, Belgium). To enable the comparison between gels, a mixture of 10 well resolved $16 \mathrm{~S}$ rRNA gene clones (Newcastle University) was loaded in each gel and used as markers on the left, middle and right hand lanes.

\subsection{Statistical analysis}

Multivariate pattern recognition was performed using the PLSDiscriminant Analysis (PLS-DA), SIMCA-P software package (ver-

Table 1

Primes used for PCR amplification.

\begin{tabular}{lll}
\hline Primers & \multicolumn{1}{c}{ Sequences $\left(5^{\prime}-3^{\prime}\right)$} & \multicolumn{1}{c}{ Reference } \\
\hline FGPH19 & TAC GGC AAR GGT GGN ATH G & Simonet et al. (1991) \\
PolR & ATS GCC ATC ATY TCR CCG GA & Poly et al. (2001b) \\
AQER & GAC GAT GTA GAT YTC CTG & Poly et al. (2001b) \\
PolF-GC & TGC GAY CCS AAR GCB GAC TC & Poly et al. (2001b) \\
\hline
\end{tabular}

$\mathrm{R}=\mathrm{A} / \mathrm{G} ; \mathrm{N}=\mathrm{A} / \mathrm{G} / \mathrm{C} / \mathrm{T} ; \mathrm{H}=\mathrm{T} / \mathrm{C} / \mathrm{A} ; \mathrm{Y}=\mathrm{C} / \mathrm{T} ; \mathrm{S}=\mathrm{G} / \mathrm{C}$.

a GC clamp = CGCCCGCCGCGCCCCGCGCCCGGCCCGCCGCCCCCGCCCC. 
sion 10.0, Umetrics AB, Umeå, Sweden). As a priori information (independent variable) only the replicates were used. No information concerning the expected grouping of samples was provided.

\subsection{Sequencing of excised nifH-DGGE bands and phylogenetic analysis}

Bands excised from the DGGE gels were eluted in $50 \mu$ l of water ( $4{ }^{\circ} \mathrm{C}$ overnight). Each supernatant $(1 \mu \mathrm{l})$ was used as the PCR template with the primers PolF (without GC clamp) and AQER, as described above. The PCR products were purified using the ExoSAPIT purification kit (GE Healthcare, Uppsala, Sweden), according to the manufacturer's instructions. Sequencing was performed with the automated sequencer ABI-Prism 370 (Applied Biosystems, Foster City, CA, USA) using the ABI-Prism sequencing kit and the primer AQER. The nifH sequences obtained were identified by BLAST-N analyses using the GenBank database (http://blast.ncbi.nlm.nih.gov/blast.cgi). All sequences obtained in this study have been submitted to the GenBank database under accession numbers EU750895 to EU750905, EU750907 and EU750908.

\subsection{Real-time PCR assays}

nifH gene abundance was quantified by real-time PCR (qPCR) using the primers PolF and PolR primer (Poly et al., 2001b). qPCR was performed using a LightCycler instrument (Roche) and a SYBR Green I fluorophore protocol as recommended by the manufacturer. Amplification was carried out in $20 \mu \mathrm{l}$ reaction volumes containing $5 \mu \mathrm{l}$ of diluted template DNA, $300 \mathrm{nM}$ of each primer, $9 \mu \mathrm{l}$ of PCR-grade water and $4 \mu \mathrm{l}$ of LightCycler Faststart ${ }^{\text {plus }}$ DNA Master SYBR Green I (Roche, Mannheim, Germany). All amplifications were performed in triplicate. PCR-grade water (no template) was used as a negative control throughout. Thermal cycling for the assays consisted of $95{ }^{\circ} \mathrm{C}$ for $10 \mathrm{~min}$, followed by $30-40$ cycles of denaturation at $95{ }^{\circ} \mathrm{C}$ for $15 \mathrm{~s}$, annealing at $55^{\circ} \mathrm{C}$ for $10 \mathrm{~s}$, and elongation at $72{ }^{\circ} \mathrm{C}$ for $15 \mathrm{~s}$. Fluorescence signals were measured once per cycle at the end of the denaturation step. After amplification, a melting curve was obtained by heating the products to $95^{\circ} \mathrm{C}$, cooling them to $65^{\circ} \mathrm{C}$ and then gradually heating them to $95{ }^{\circ} \mathrm{C}$ at a rate of $0.2^{\circ} \mathrm{C} / \mathrm{s}$. The specificity of the qPCR products was confirmed by melting curve analysis and gelbased post-PCR analysis. A sample was only considered positive if it exhibited a log-linear (exponential) amplification in the fluorescence curve and either a specific peak in the melting curve (between 85 and $92{ }^{\circ} \mathrm{C}$ for nifH gene assays), or showed a specific band with the expected fragment size on a 1.5\% agarose gel. Triplicate results of real-time PCR measurements were averaged and the standard error was calculated. Standard curves were constructed for each primer set based on triplicate 10-fold dilutions of a DNA standard containing a known number of target gene copies using procedures recommended by the manufacturer (Roche LightCycler software).

\section{Results}

\subsection{DGGE analysis of the nitrogen-fixing bacteria}

DNA was recovered from all rhizosphere samples-two cultivars (BRS 308 and BRS 310) with low and high nitrogen fertilizer (12 and $120 \mathrm{~kg} /$ ha respectively) and also from bulk soil samples. All DNA samples (six in triplicate) were successfully amplified using the nested PCR protocol described in materials and methods. The resulting 320 bp-nifH gene fragments were then resolved by DGGE. Highly reproducible DGGE profiles (with only minor differences) were obtained among triplicates from bulk and rhizosphere soil samples (Fig. 1a and b). On the other hand, different banding patterns were observed between samples (Fig. 1). PCR amplified nifH gene fragments from rhizosphere and bulk soil samples revealed marked shifts in diazotrophic community composition in response to the presence of the plant (sorghum rhizosphere vs non-rhizosphere soils), cultivar type (BRS 308 vs BRS 310) and amount of fertilizer used (low nitrogen vs high nitrogen inputs). In general, a greater diversity of nifH gene fragments (band richness) was observed in the rhizosphere soil of cultivar BRS 308 than of cultivar BRS 310. In addition, the diazotrophic community present in the rhizosphere of both cultivars was affected by the high amount of nitrogen fertilizer used, since both the band richness and intensity were reduced in this condition. (a)

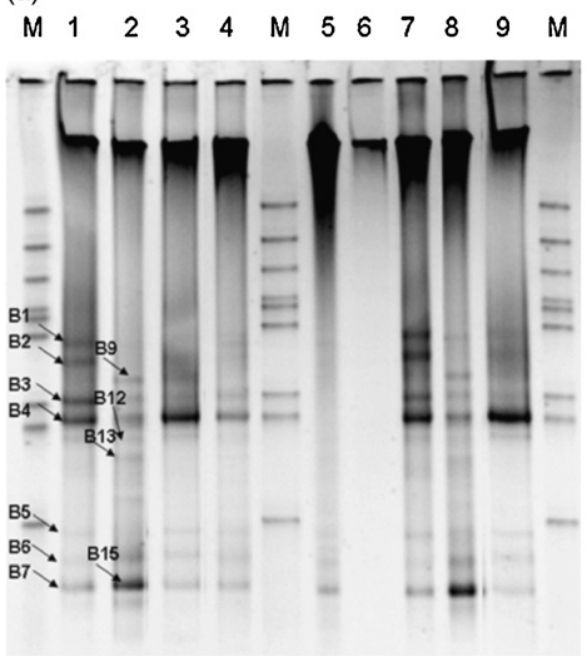

(b)

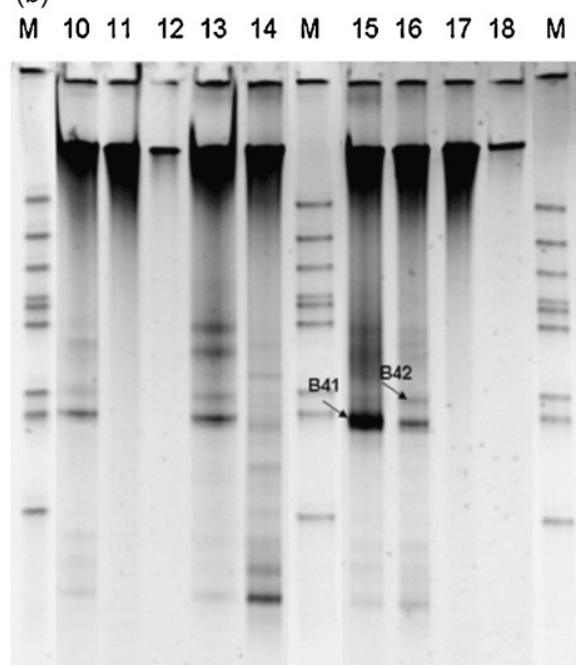

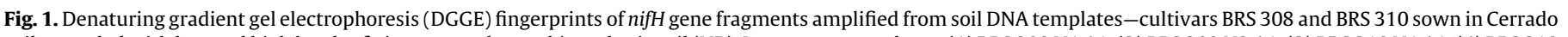

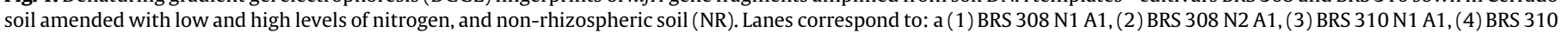

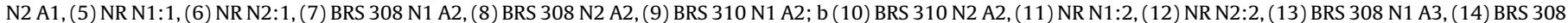

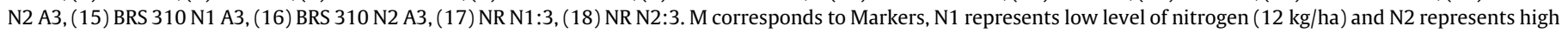
level of nitrogen $(120 \mathrm{~kg} / \mathrm{ha}) ; \mathrm{A} 1, \mathrm{~A} 2$ and $\mathrm{A} 3$ represent replicates. Arrows indicate the bands that were extracted from the gel, reamplified, and sequenced. 


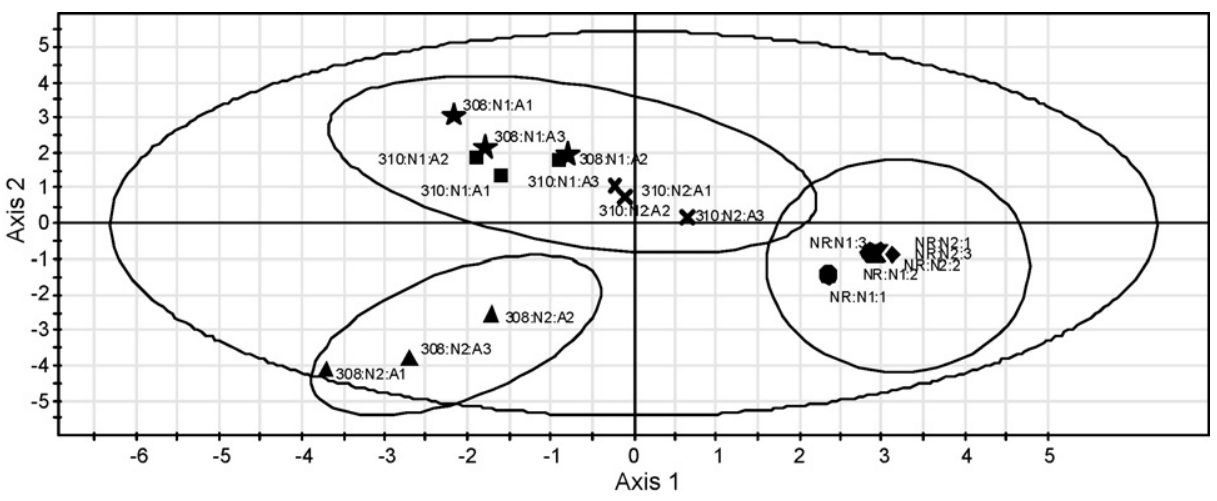

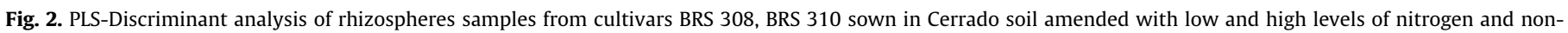
rhizospheric soil (NR). N1 represents low level of nitrogen (12 kg/ha) and N2 represents high level of nitrogen (120 kg/ha); A1, A2 and A3 represent replicates.

Table 2

Identification by NCBI BlastN (first hit and most similar sequences from known diazotrophic bacteria) of nifH sequences retrieved from DGGE bands.

\begin{tabular}{|c|c|c|c|c|c|}
\hline Band & Closest match & \% identity & Closest match (cultured) & \% identity & Phylogenetic position $^{\mathrm{a}}$ \\
\hline Band 01 & Uncultured bacterium clone IS110 EU048166.1 & $98 \%$ & Mesorhizobium loti AB367742.1 & $96 \%$ & $\alpha$; Rhizobiales \\
\hline Band 02 & Uncultured bacterium clone IPA74 EU048016.1 & $93 \%$ & Azohydromonas australica AB188121.1 & $88 \%$ & $\beta$; Burkholderiales \\
\hline Band 03 & Uncultured bacterium clone IS110 EU048166.1 & $97 \%$ & Mesorhizobium loti AB367742.1 & $94 \%$ & $\alpha$; Rhizobiales \\
\hline Band 04 & Klebsiella pneumoniae AY242355.1 & $96 \%$ & & - & $\gamma$; Enterobacteriales \\
\hline Band 05 & Azohydromonas lata AB188122.1 & $98 \%$ & & - & $\beta$; Burkholderiales \\
\hline Band 06 & Uncultured bacterium clone IS98 EU048155.1 & $92 \%$ & Mesorhizobium loti AB367742.1 & $90 \%$ & $\alpha$; Rhizobiales \\
\hline Band 07 & Uncultured bacterium clone IS110 EU048166.1 & $96 \%$ & Mesorhizobium loti AB367742.1 & $94 \%$ & $\alpha$; Rhizobiales \\
\hline Band 09 & Klebsiella pneumoniae AY242355.1 & $98 \%$ & & - & $\gamma$; Enterobacteriales \\
\hline Band 12 & Uncultured bacterium clone IS92 EU048149.1 & $99 \%$ & Delftia tsuruhatensis AY544164.1 & $98 \%$ & $\beta$; Burkholderiales \\
\hline Band 13 & Uncultured bacterium clone IS41 EU048099.1 & $98 \%$ & Bradyrhizobium sp. AB079620.1 & $92 \%$ & $\alpha$; Rhizobiales \\
\hline Band 15 & Uncultured bacterium clone DQ995905.1 & $94 \%$ & Azospirillum brasilense & $91 \%$ & $\alpha$; Rhodospirillales \\
\hline Band 41 & Uncultured bacterium clone IS110 EU048166.1 & $97 \%$ & Mesorhizobium loti AB367742.1 & $94 \%$ & $\alpha$; Rhizobiales \\
\hline Band 42 & Uncultured bacterium clone IPA69 EU048011.1 & $98 \%$ & Mesorhizobium loti AB367742.1 & $94 \%$ & $\alpha$; Rhizobiales \\
\hline
\end{tabular}

${ }^{a} \alpha$, Alphaproteobacteria; $\beta$, Betaproteobacteria; $\gamma$, Gammaproteobacteria.

\subsection{Comparison of community structure}

A total of 17 different band positions could be identified in DGGE profiles and used for multivariate statistical analysis (PLSDA). As a result, the samples could be separated into 3 groups: (i) cultivar BRS 308 sown with high levels of nitrogen, (ii) BRS 308 sown with low levels of nitrogen and BRS 310 sown with either low or high levels of nitrogen and (iii) non-rhizosphere soil (Fig. 2). This pattern of grouping indicates that the nitrogen amount applied in soil had an influence over the cultivar BRS 308 nitrogen-fixing populations but not over those from BRS 310 . Hence, the sorghum cultivar type does not seem to influence the diversity of the nitrogen-fixing community found in rhizospheres under low levels of applied nitrogen. Moreover, the rhizosphere of both cultivars appears to select specific diazotrophs, as a statistically different population could be observed in bulk soil.

\subsection{Phylogenetic analysis}

Thirteen bands were retrieved from the DGGE gels, reamplified, and sequenced. BLAST-N analyses revealed that 10 bands (77\%) were closely related to nifH genes of uncultured bacteria, and the remaining nifH sequences were affiliated with Klebsiella pneumoniae (two sequences) or Azohydromonas lata (Table 2). Since $77 \%$ of the clones matched most closely with nifH genes from uncultured organisms, the first hit in BLAST-N matching to a culturable strain was also considered. Hence, the clones were affiliated with known diazotrophs such as Mesorhizobium loti, Azohydromonas australica, Delftia tsuruhatensis, Bradyrhizobium sp. and Azospirillum brasilense. Details of the sequence identities and their percentages of similarities are given in Table 2.

\section{4. nifH gene quantification}

Triplicate results of real-time PCR measurements were averaged and the standard error was calculated. The assays were highly reproducible and the standard error was low. The nifH gene abundance ranged from $2.4 \times 10^{5}$ to $1.3 \times 10^{7}$ copies $/ g$ of soil (Fig. 3). The number of nifH genes detected in the rhizosphere soil of the two cultivars submitted to different fertilizer regimes varied markedly. Overall, diazotroph numbers (as determined by nifH gene abundance) were higher in the rhizospheres than in the nonrhizosphere soils. This suggests that the presence of the plant promotes diazotrophy. Higher nifH gene abundance was observed

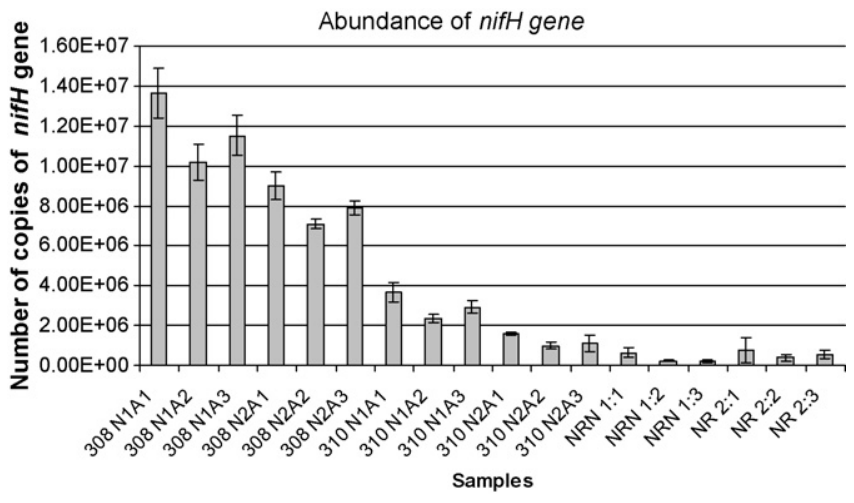

Fig. 3. Quantification of nifH gene copies in samples from cultivars BRS 308 , BRS 310 sown in Cerrado soil amended with low and high levels of nitrogen and nonrhizospheric soil (NR). N1 represents low level of nitrogen (12 kg/ha) and N2 represents high level of nitrogen $(120 \mathrm{~kg} / \mathrm{ha}) ; \mathrm{A} 1, \mathrm{~A} 2$ and $\mathrm{A} 3$ represent replicates. 
in the rhizosphere from cultivar BRS 308 than that from cultivar BRS 310 and bulk soil. Fertilizer input also influenced diazotroph populations since there was a significant decrease in nifH gene abundance in rhizosphere soil from both cultivars when high rates of nitrogen were applied to the crops. This was not observed in the non-rhizosphere soil where nifH gene abundance remained similar regardless to nitrogen inputs.

\section{Discussion}

The molecular diversity and the quantity of the nifH gene sequences in the rhizospheres of two cultivars of sorghum sown in Cerrado soil with contrasting levels of nitrogen fertilizer were assessed by nifH PCR-DGGE and qPCR analyses. For the amplification of the nifH gene from the rhizosphere and bulk soils, a nested PCR approach proved to be necessary since the number of nitrogen fixers are usually low when compared with the whole microbial community. Although diazotrophs are highly adapted to different soil physical and chemical conditions, diazotrophic bacteria are rarely dominant in terrestrial ecosystems (Tate, 1995). For example, in forest soils, only approximately $5 \%$ of the clones from 16S rDNA clone libraries could be related with nitrogen-fixing bacteria (Widmer et al., 1999; Mergel et al., 2001). However, biological nitrogen fixation is considered a very important source of nitrogen input in soil (Demba Diallo et al., 2004; Wartiainen et al., 2008).

The denaturing gradient gel electrophoresis fingerprints obtained for the nitrogen-fixing communities analyzed here showed that, regardless of different sorghum cultivars, the rhizospheres harbored populations more diverse than those found in bulk soil. The data presented here can be related to a rhizosphere effect, with an increased microbial activity in the area surrounding the root (Bowen and Rovira, 1991). In addition, a greater diversity of nifH gene fragments (band richness) was observed in the rhizosphere soil of cultivar BRS 308 than of cultivar BRS 310 (Fig. 1), indicating that the structure of the nitrogen-fixing community of the two cultivars is different. Therefore, the results presented here emphasize the importance of the cultivar type when selecting nitrogen-fixing strains for use as sorghum inoculants. Based on culture methods, a linear relationship between the cultivar and bacterial community has been reported by García de Salamone et al. (1996) for maizegenotype association with Azospirillum and by Carelli et al. (2000) for alfalfa cultivars and Sinorhizobium. Similar results have been observed by Coelho et al. (2007) for sorghum cultivars and Paenibacillus using a molecular approach.

One advantage of DGGE analysis is that the DNA can be extracted from the gels, the sequence analyzed on the purified amplicons enabling the identification of bacterial members of the rhizosphere community. In this study, the amplified DNA sequences from uncultured environmental clones were prevalent. These clones may represent novel sequences of nitrogen-fixing bacteria. Clones that could not be affiliated with any culturable strain have been found in other microbial ecology studies (Izquierdo and Nusslein, 2006; Buckley et al., 2007; Coelho et al., 2008; Wartiainen et al., 2008). When the first hit related to a culturable bacterium was considered in BLAST, Rhizobiales was the major order found. The high abundance of Alphaproteobacteria nifH genes found could be explained by crop rotation with leguminous plants (soybean) in the sites where the sorghum was collected. Moreover, the roots of different non-leguminous plants (rice, maize and wheat) can be colonized by rhizobia (Yanni et al., 1997; Chaintreuil et al., 2000; Gutierrez-Zamora and Martinez-Romero, 2001).

Discriminant analysis based on DGGE profiles showed that contrasting fertilizer regimes (12 and $120 \mathrm{~kg} / \mathrm{ha}$ ) had little influence on the nifH gene pool diversity in cultivar BRS 310 but high influence in cultivar BRS 308 (Fig. 2). This result suggests that the community structures of both cultivars respond differently to nitrogen fertilizer regimes. However, assessment by qPCR of the two cultivars of sorghum sown with contrasting levels of nitrogen fertilizer showed that the abundance of nifH copies decreased in both rhizospheres when the high amount of fertilizer was used (Fig. 3). This trend was not observed in bulk soil where a very low diazotroph density was detected and nifH gene abundance was similar regardless the fertilizer treatment used. The decrease in nifH gene abundance observed in both cultivars could be explained by the sensitivity of certain bacterial groups present in their rhizospheres to nitrogen fertilizer. Wu et al. (2009) have already demonstrated that the relative abundance of Alphaproteobacteria in the nifH gene pools was dramatically decreased with nitrogen fertilizer application. However, it is important to draw attention to other investigations on the controvertial effect of nitrogen fertilizers on the microbial population in soil (Knauth et al., 2005; Roesch et al., 2006). A remarkable stability in the rhizosphere's diazotrophic population was observed after addition of nitrogen fertilizers (Bagwell and Lovell, 2000; Piceno and Lovell, 2000). Moreover, Juraeva et al. (2006) demonstrated that the relative abundance of the nifH gene pool in cucumber roots was, unexpectedly, positively correlated with nitrogen supply. In conclusion, the amount of nitrogen fertilizer affects the nitrogen-fixing bacteria present in plant rhizospheres in different ways, depending not only on the plant species and/or cultivar, but also possibly on plant age and on key diazotrophs present in a particular environment. In the present study, the abundance of nifH genes in the rhizosphere of two sorghum cultivars differed significantly between them (greater in cultivar BRS 308) and when two different levels of nitrogen fertilizer were applied (Fig. 3). Therefore, we conclude that both cultivar and the amount of added nitrogen may influence diazotrophic population densities for sorghum planted in Cerrado soil.

\section{Acknowledgements}

This work was supported by grant from CAPES (Coordenação de Aperfeiçoamento de Pessoal de Nível Superior) to MRRC. Financial support was also provided by research grants from the National Research Council of Brazil (CNPq) and FAPERJ.

\section{References}

Bagwell, C.E., Lovell, C.R., 2000. Persistence of selected Spartina alterniflora rhizoplane diazotrophs exposed to natural and manipulated environmental variability. Appl. Environ. Microbiol. 66, 4625-4633.

Bowen, G.D., Rovira, A.D., 1991. In: Waisel, Y., Eschel, A., Kafkafi, U. (Eds.), Plant Roots: The Hidden Half. Marcel Dekker, New York, pp. 349-388.

Buckley, D.H., Huangyutitham, V., Hsu, S., Nelson, T.A., 2007. Stable isotope probing with ${ }^{15} \mathrm{~N}_{2}$ reveals novel noncultivated diazotrophs in soil. Appl. Environ. Microbiol. 73, 3196-3204.

Carelli, M., Gnocchi, S., Francelli, S., Mengoni, A., Paffetti, D., Scotti, C., Bazzicalupo, M., 2000. Genetic diversity and dynamics of Sinorhizobium meliloti populations nodulating different alfafa cultivars in Italian soils. Appl. Environ. Microbiol. 66, 4785-4789.

Chaintreuil, C., Giraud, E., Prin, Y., Lorquin, J., Bâ, A., Gillis, M., de Lajudie, P., Dreyfus, B., 2000. Photosynthetic Bradyrhizobia are natural entophytes of the African wild rice Oryza breviligulata. Appl. Environ. Microbiol. 66, 5437-5447.

Church, M.J., Jenkins, B.D., Karl, D.M., Zehr, J.P., 2005a. Vertical distributions of nitrogen-fixing phylotypes at Stn ALOHA in the oligotrophic North Pacific Ocean. Aquat. Microb. Ecol. 38, 3-14.

Church, M.J., Short, C.M., Jenkins, B.D., Karl, D.M., Zehr, J.P., 2005b. Temporal patterns of nitrogenase (nifH) gene expression in the oligotrophic North Pacific Ocean. Appl. Environ. Microbiol. 71, 5362-5370.

Coelho, M.R.R., de Vos, M., Carneiro, N.P., Marriel, I.E., Paiva, E., Seldin, L., 2008 Diversity of nifH gene pools in the rhizosphere of two cultivars of sorghum (Sorghum bicolor) treated with contrasting levels of nitrogen fertilizer. FEMS Microbiol. Lett. 279, 15-22.

Coelho, M.R.R., Mota, F.F., Carneiro, N.P., Marriel, I.E., Paiva, E., Rosado, A.S., Seldin, L., 2007. Diversity of Paenibacillus spp. in the rhizosphere of four sorghum (Sorghum bicolor) cultivars sown with two contrasting levels of nitrogen fertilizer accessed by rpoB-based PCR-DGGE and sequencing analysis. J. Microbiol. Biotechnol. 17, 753-760. 
Deslippe, J., Egger, K., 2006. Molecular diversity of nifH genes from bacteria associated with high arctic dwarf shrubs. Microb. Ecol. 51, 516-525.

Demba Diallo, M., Willems, A., Vloemans, N., Cousin, S., Vandekerckhove, T.T., de Lajudie, P., Neyra, M., Vyverman, W., Gillis, M., Van der Gucht, K., 2004 Polymerase chain reaction denaturing gradient gel electrophoresis analysis of the $\mathrm{N}_{2}$-fixing bacterial diversity in soil under Acacia tortilis ssp. raddiana and Balanites aegyptiaca in the dryland part of Senegal. Environ. Microbiol. 6, 400-415.

García de Salamone, I., Döbereiner, J., Urquiaga, S., Boddey, R.M., 1996. Biological nitrogen fixation in Azospirillum strain-maize genotype association as evaluated by ${ }^{15} \mathrm{~N}$ isotope dilution technique. Biol. Fertil. Soils 23, 249-256.

Gray, N.D., Head, I.M., 2001. Linking genetic identity and function in communities of uncultured bacteria. Environ. Microbiol. 3, 481-492.

Griffiths, R.I., Whiteley, A.S., O'Donnell, A.G., Bailey, M.J., 2000. Rapid method for coextraction of DNA and RNA from natural environments for analysis of ribosomal DNA- and rRNA-based microbial community composition. Appl. Environ. Microbiol. 66, 5488-5491.

Gutierrez-Zamora, M.L., Martinez-Romero, E., 2001. Natural endophytic association between Rhizobium etli and maize (Zea mays L.). J. Biotechnol. 91, 117-126.

Izquierdo, J.A., Nusslein, K., 2006. Distribution of extensive nifH gene diversity across physical soil microenvironments. Microb. Ecol. 51, 441-452.

Juraeva, D., George, E., Davranov, K., Ruppel, S., 2006. Detection and quantification of the nifH gene in shoot and root of cucumber plants. Can. J. Microbiol. 52, 731739.

Kanungo, P.K., Kamakrishnan, B., Rao, V.R., 1997. Placement effects of organic sources on nitrogenase activity and nitrogen-fixing bacteria in flooded rice soils. Biol. Fertil. Soils 25, 103-108.

Knauth, S., Hurek, T., Brar, D., Reinhold-Hurek, B., 2005. Influence of different Oryza cultivars on expression of nifH gene pools in roots of rice. Environ. Microbiol. 7, 1725-1733.

Lovell, C.R., Piceno, Y.M., Quattro, J.M., Bagwell, C.E., 2000. Molecular analysis of diazotroph diversity in the rhizosphere of the smooth cordgrass, Spartina alterniflora. Appl. Environ. Microbiol. 66, 3814-3822.

Mergel, A., Schmitz, O., Mallmann, T., Bothe, H., 2001. Relative abundance of denitrifiying and dinitrogen-fixing bacteria in layers of a forest soil. FEMS Microbiol. Ecol. 36, 33-42.

Peoples, M.B., Craswell, E.T., 1992. Biological nitrogen fixation: investments, expectations and actual contributions to agriculture. Plant Soil 141, 13-39.

Piceno, Y.M., Lovell, C.R., 2000. Stability in natural bacterial communities. I. Nutrient addition effects on rhizosphere diazotroph assemblage composition. Microb. Ecol. 39, 32-40.

Poly, F., Monrozier, L.J., Bally, R., 2001b. Improvement in the RFLP procedure for studying the diversity of nifH genes in communities of nitrogen fixers in soil. Res. Microbiol. 152, 95-103.
Poly, F., Ranjard, L., Nazaret, S., Gourbière, F., Monrozier, L.J., 2001a. Comparison of nifH gene pools in soil and soil microenvironments with contrasting properties. Appl. Environ. Microbiol. 67, 2255-2262.

Roesch, L.F.W., Olivares, F.L., Passaglia, L.M.P., Selbach, P.A., Saccol de Sa, E.L., Oliveria de Camargo, F.A., 2006. Characterization of diazotrophic bacteria associated with maize: effect of plant genotype, ontogeny and nitrogen supply. World J. Microbiol. Biotechnol. 22, 967-974.

Short, S.M., Zehr, J.P., 2005. Quantitative analysis of nifH genes and transcripts from aquatic environments. Methods Enzymol. 397, 380-394.

Simonet, P., Grojean, M.C., Misra, A.K., Nazaret, S., Cournoyer, B., Normand, P., 1991. Frankia genus-specific characterization by polymerase chain reaction. Appl. Environ. Microbiol. 57, 3278-3286.

Tan, Z., Hurek, T., Reinhold-Hurek, B., 2003. Effect of N-fertilization, plant genotype and environmental conditions on nifH gene pools in roots of rice. Environ. Microbiol. 5, 1009-1015.

Tate, R.L., 1995. Nitrogen fixation. In: Tate, R.L. (Ed.), The Gateway to Soil Nitrogen Cycling. John Wiley and Sons, Inc., Hoboken, NJ, USA, pp. 283-306.

Ueda, T., Suga, Y., Yahiro, N., Matsuguchi, T., 1995. Remarkable $\mathrm{N}_{2}$-fixing bacterial diversity detected in rice roots by molecular evolutionary analysis of nifH gene sequences. J. Bacteriol. 177, 1414-1417.

Wallenstein, M.D., Vilgalys, R.J., 2005. Quantitative analyses of nitrogen cycling genes in soils. Pedobiologia 49, 665-672.

Wartiainen, I., Eriksson, T., Zheng, W., Rasmussen, U., 2008. Variation in the active diazotrophic community in rice paddy-nifH PCR-DGGE analysis of rhizosphere and bulk soil. Appl. Soil Ecol. 39, 65-75.

Widmer, F., Shaffer, B.T., Porteous, L.A., Seidler, R.J., 1999. Analysis of nifH gene pool complexity in soil and litter at Douglas fir forest site in the Oregon cascade mountain range. Appl. Environ. Microbiol. 65, 374-380.

Wu, L., Ma, K., Lu, Y., 2009. Prevalence of Betaproteobacterial sequences in nifH gene pools associated with roots of modern rice cultivars. Microb. Ecol. 57, 58-68.

Yanni, Y.G., Rizk1, R.Y., Corich, V., Squartini, A., Ninke, K., Philip-Hollingsworth, S., Orgambide, G., de Bruijn, F., Stoltzfus, J., Buckley, D., Schmidt, T.M., Mateos, P.F., Ladha, J.K., Dazzo, F.B., 1997. Natural endophytic association between Rhizobium leguminosarum bv. trifolii and rice roots and assessment of its potential to promote rice growth. Plant Soil 194, 99-114.

Young, J.P.W., 1992. Phylogenetic classification of nitrogen-fixing organisms. In: Stacey, G., Burris, R.H., Evans, H.J. (Eds.), Biological Nitrogen Fixation. Chapman and Hall, New York, NY, pp. 43-86.

Zehr, J.P., Jenkins, B.D., Short, S.M., Steward, G.F., 2003. Nitrogenase gene diversity and microbial community structure: a cross-system comparison. Environ. Microbiol. 5, 539-554.

Zhang, Y., Li, D., Wang, H., Xiao, Q., Liu, X., 2006. Molecular diversity of nitrogenfixing bacteria from the Tibetan Plateau, China. FEMS Microbiol. Lett. 260, 134 142 . 